\title{
Local language programs in cultural radios to maintain Indonesian national identity
}

\author{
Dwi Wahyuningtyas' ${ }^{1}$ Ade Kusuma1, Roziana Febrianita1, Zainal Abidin Achmad ${ }^{1 *}$ \\ ${ }_{1}^{1}$ Universitas Pembangunan Nasional Veteran Jawa Timur, Indonesia \\ *Correspondence author: z.abidinachmad@upnjatim.ac.id
}

\begin{tabular}{|c|c|}
\hline ARTICLE INFO & ABSTRACT \\
\hline $\begin{array}{l}\text { Keywords: } \\
\text { cultural radio; local } \\
\text { culture; national identity; } \\
\text { virtual ethnography. } \\
\text { How to cite: } \\
\text { Wahyuningtyas, D., } \\
\text { Kusuma, A., Febrianita. } \\
\text { R., Achmad, Z.A. (2021). } \\
\text { Local language programs } \\
\text { in cultural radios to } \\
\text { maintain Indonesian } \\
\text { national identity. Etnosia: } \\
\text { Jurnal Etnografi } \\
\text { Indonesia, 6(1), } 47 \text { - } 65 . \\
\\
\text { DOI: } \\
\text { 10.31947/etnosia.v6i1.11973 }\end{array}$ & $\begin{array}{l}\text { Private radio, which relies on programs with local cultural content in } \\
\text { local languages, affects the success of reaching large audiences and } \\
\text { financial benefits. In East Java, four private radios have the advantage } \\
\text { of local cultural programs, namely Radio Jodhipati FM in Nganjuk, } \\
\text { Radio Sritanjung FM in Banyuwangi, Radio Nada FM Sumenep, and } \\
\text { Radio Media FM in Surabaya. This study aims to determine what } \\
\text { cultural programs can increase the number of listeners and } \\
\text { profitability on the four cultural radios. Furthermore, to find out why } \\
\text { listeners like local cultural programs of each radio. This research on } \\
\text { broadcast content on four cultural radios uses virtual ethnographic } \\
\text { methods by collecting data, both offline and online. Researchers are } \\
\text { involved in broadcasting activities on four cultural radios (offline) and } \\
\text { listener interaction activities in the virtual world (online), namely } \\
\text { Facebook and WhatsApp. This study conducted interviews with } \\
\text { twelve informants representing radio management, local cultural } \\
\text { figures, and loyal listeners. The results showed that each radio has } \\
\text { excellent cultural programs with a solid appeal to maintain listener } \\
\text { loyalty. The four cultural radios involve cultural experts in designing } \\
\text { cultural programs. Listeners try to maintain local tastes because they } \\
\text { realize that love for local culture is a strengthening of national } \\
\text { identity, which is the richness of Indonesian culture. }\end{array}$ \\
\hline
\end{tabular}

\section{Introduction}

From 2016 to 2018, researchers have made observations in the province of East Java to trace private radios' existence that have the characteristics of local cultural programs as the main content of broadcasts. Based on preliminary data from the East Java PRSSNI regarding the positioning of private radio members (PRSSNI Jawa Timur, 2018), only four East Java PRSSNI members explicitly used Indonesian cultural identity positioning.

These radios include Radio Nada FM with the slogan "Madura Station" (Ardiansyah, 2017; Achmad., 2019), Radio Sritanjung FM with the slogan "Radioe Lare Using" (Arps, 2009), which changed to "Pride of Banyuwangi" (Achmad, 2020a), Radio Cakrawala FM with the slogan "Campursari Thok Wes," Radio Media FM with the slogan "Campursari Media." Meanwhile, one other radio is not a member of the East Java PRSSNI but famous 
as a Javanese cultural radio, namely Jodhipati FM Nganjuk Radio (Achmad and Ida, 2019). The number of private radios with cultural positioning is minimal when compared to the number of radio members of PRSSI East Java (6 AM radios and $85 \mathrm{FM}$ radios) or even compared to the total number of private radios (AM and FM) in East Java, which totals 164 radios (10 AM radio and 154 FM radio).

Initial difficulties when tracing private radio stations with cultural positioning were resolved, with the help of two East Java radio figures, Mr. Luthfi Abdullah and Mr. Djoko W. Tjahjo. Both gave the advice to look at the streaming broadcasts of all private radio stations in East Java, specifically cultural slogans, or mottos. The advice is in line with the study on radio slogans and mottos, stating that radio slogans have ties and links with community representation. Not infrequently, radio slogans come up from the radio listeners community and not from the radio management (Warren, 2005; Stewart, 2010; Kessler, 2012; Lloyd, 2015).

For example, the radio slogan given by the community of its listeners was Radio Nada FM, with the slogan Madura Station and Radio Sritanjung FM with the slogan Radioe Lare Using. Madura Station which derives from a Madurese term views radio Nada FM as a Madurese radio. This proves the high trust from the public and religious leaders (Kyai and Nyai) from islamic boarding schools in Sumenep to Radio Nada FM as a radio that totally uses Madurese language in its broadcast (Ardiansyah, 2017). Also, it happened when the title Radioe Lare Using was given to Radio Sritanjung FM. Because of its commitment to use Using language in its broadcast, this radio becomes a pride icon of Banyuwangi people (Arps, 2009).

Four private radio stations that become the subjects of this research deserve to be called as cultural radio, because they have commitments to broadcast local contents with local language as a broadcast introduction (Achmad and Ida, 2019; Achmad., 2019). There are some differences in naming the radio that broadcasts cultural contents. Some academicians categorize them as community radio (Forde, Foxwell and Meadows, 2002; Al-hassan, Andani and Abdul-malik, 2011; King, 2015; Faisal and Alhassan, 2018). Meanwhile, other academician groups define a radio that broadcasts arts as an art and community radio (Cochrane et al., 2008).

In its intense competition, the foresight to decide broadcasting format, specific segmentation, positioning determination, broadcasting format, segmentation and music format become important (Rothenbuhler, 1996; Warren, 2005; Achmad and Alamiyah, 2015). The success to manage all those processes guarantee the success of a radio business that has a core business for ideas marketing (Sweeting, 2007; Setianingrum, 2012; Inkinen and Tuominen, 2013). The embodiment of those ideas is a broadcasting program which is loved by the listeners and the advertisers (Barber, 2010). An important guideline in positioning determination is the adjustment with the culture of the listeners (Walker, 2004).

The cultural radio phenomenon is very unique, because local culture contents (songs, music, arts and culture, and local language) are actually really loved by the listeners and become the best selling item to the advertisers (mainly local advertisers). The loyal listeners even increase and its scope expands to foreign countries (Achmad and Ida, 
2019; Achmad., 2019). The ability to survive of those cultural radios and their cultural programs that become the main commodity and the source of profit for those four cultural radios will be observed by using ethnography visual method that collected the data both online and offline, visit and interact directly with the subjects of the research in the real and virtual world.

A cultural radio has some advantages compared to other private radios, because it has a strong positioning and broadcasting content which is closely related to local culture (Nguyen, 2008). The other strength is having a strong interaction with its loyal listeners (Mytton, 1992; King, 2015; Wilkinson, 2015). A cultural radio applies the consolidation of work model between the broadcasters and listeners of the radio, make them close, and give a chance to the listeners to take part as a content producer (Benjamin, 2005). A cultural radio obediently provides the needs of the loyal listeners, and it has a social role so that it can survive (Gilloch, 2002).

The closeness between the broadcaster and the listeners are facilitated more with the presence of internet as a platform of broadcasting (Benkler, 2006). Those four cultural radios (Radio Jodhipati FM, Radio Nada FM, Radio Media FM, and Radio Sritanjung FM) have shown that the adaptation stage is heading to convergence. Those four radios did a mediamorphosis by using internet platform media such as Facebook, Youtube, Instagram, and Whatsapp to support the brodcasting. A cultural radio develops a different way of broadcasting by using some web-based communication platforms as a platform to deliver the broadcasting contents (May, 2013). Through the use of internet for broadcasting, those four cultural radios try to fulfill the needs of their listeners, because the listeners now have changed their role into a public actor, whose opinion is worth listening, convergent and has a network (Bonini, 2014; Achmad, 2020a).

The word convergence in this research means the process of accelerating the flow of media content to various communication channels. This is absolutely to expand the market, gain more profit, and increase the number of customers. On the other hand, convergence is customers' effort to renew the use and mastery of technology to keep updated. Convergence has many meanings depending on the study field that is used (Albarran, Mierzejewska and Jung, 2006; Wirth, 2006; Storsul and Stuedahl, 2007; Storsul and Fagerjord, 2010; Schneider, 2012). However, there is one best term that can explain convergence in a more understandable definition, that is governance. Media convergence means the change of governance to the rise of a new communication technology (Schneider, 2012).

Convergence is the peak of a mediamorphosis process. Mediamorphosis process is presented to explain various changes of technology use made by those four cultural radios. Mediamorphosis is an integrated ways of thinking to understand the evolution of communication media technology (Fidler, 1997; Achmad, 2020b). Mediamorphosis explains that various forms of media are components of an interrelated system and reveals the similarity relations with media forms in the past, present, and future. The emergence of new media did not kill the old media, but made the old media adapt and continue to develop (Baltzis, 2004).

Theoretically, Roger Fidler explains the six principles of mediamorphosis, including: (1) 
Coevolution and coexistence, that old and new communication technologies exist and adapt to each other, (2) Metamorphosis, that the emergence of new media takes place gradually from the form of media predecessor. For example, the invention of streaming technology, does not necessarily make analog radio broadcasts (broadcast) dead. (3) Inheritance, that the emergence of new media technologies inherits the dominant character of the media predecessor. (4) Ability to survive, the birth of new media forms made the previous media adapt to survive the times. (5) Opportunities and needs, that the presence of new media technology opens up opportunities for the development of other forms of media or other businesses. (6) Adoption of delayed technology, that new technology does not immediately get success, but it takes time. Based on the research, successful technology adoption takes a generation (20-30 years) of time (Tomasello, Lee and Baer, 2010).

Because this research aims to obtain information about cultural programs that have become commodities on cultural radios, as well as to reveal the role of cultural radios in maintaining national identity, the involvement of technology use becomes a necessity for its role to be examined. Is the use of technology just talkative and following trends, or has it given special weight that broadcast support technology is an attempt to increase audience reach and advertising revenue (Akpan, 2004; Dia, 2002; O'Neill, 2007; Price et al., 2008).

\section{Method}

This study used virtual ethnography as the method of choice. This qualitative method was first used by Christine Hine as a combination of traditional ethnography and internet ethnography (Achmad \& Ida, 2018; Hine, 2000). Researchers are willing to explore real and virtual life, to carry out various activities in it within a certain time (Hine, 2000). The need for research time has the main consideration on the adequacy of the interaction with the subject, the adequacy of data acquisition and the analysis design (Angelone, 2018; Hair \& Clark, 2003; Hine, 2017).

One of the principles that proves the flexibility of the virtual ethnographic method is that the involvement of researchers can take place intermittently or in turns (Hine, 2004), which means that researchers are not constantly immersed with subjects for a long time, but can engage in participatory engagement at intervals. These researchers conducted data tracing in the real world (oflline) in January and February 2020 and conducted data tracing in the virtual world (Online) in April and May 2020, the early days of the spread of COVID-19 in Indonesia.

As participants, the researchers conducted virtual searches with personal social media accounts and personal mobile numbers to join WhatsApp groups. Researchers are obliged to reveal their identity as a condition in virtual ethnographic research. The number of informants in this study were twelve people, namely AY, JU, AS (three people from Radio Sritanjung FM); DW, SO, RN (three people from Radio Jodhipati FM); AJ, IH, IN (three people from Radio Nada FM); WD, AT, MH (three people from Radio Media FM). The composition of each radio is one announcer or programmer, one cultural expert, and one announcer. 
Researchers collect the data directly by interacting with subjects through observation and interviews (online and offline). The goal is to prove the authenticity of data sources, build trust, assess the honesty of informants, and eliminate anonymity (Schoneboom, 2007). Indirect data collection was carried out by tracing various documents related to the scope of the study (Angelone, 2018; Hine, 2017). These types of documents include profiles and portfolios of four cultural radios, articles on cultural radios, profiles of informants from various sources, articles and news related to the study, and relevant literature.

Real location tracing was carried out at offices, radio rooms and studios, local sociocultural environments, locations for off-air programs, and media habits, gathering habits, and gathering locations of the informants. Meanwhile, targeted virtual locations for search include: (1) The Web pages of four cultural radios, (2) The Facebook accounts of four cultural radios, (3) The Instagram accounts and YouTube accounts of some cultural radios, and (4) WhatsApp groups of four cultural radios.

It is necessary to explain why researchers used virtual ethnography as the method. This method has the suitability and advantages of understanding the practice of radio mediamorphosis developing towards convergence, understanding radio listeners attachments with various internet communication media, providing documentation of good broadcasting practices in the virtual world, and understanding media consumption habits (Perala et al., 2012). Media consumption includes when, where and how audiences consumed media content, how audiences use several digital channels to communicate (Deuze et al., 2007; Kusuma et al., 2020).

Researchers are intensively involved in the dynamics of the activities of listeners, broadcasters, producers and radio programmers, both real and virtual. So the choice of virtual ethnographic method is logical. Researchers carry out the theorizing process by conducting ethnographic dialogue with the members of the radio listeners community and the subjects of the study (Denzin \& Lincoln, 2000).

\section{Results and discussion}

\section{- The Roles of Cultural Radios}

Radio in the current era of convergence knows no boundaries of broadcast areas. Radio has morphed by broadcasting through the support of the internet and various communication media platforms virtually. The impact of local culture is not only enjoyed by local communities but has spread widely to foreign countries (Achmad., 2019; Achmad et al., 2020; Achmad \& Ida, 2019).

The efforts of the four cultural radios to consistently broadcast local languages, music and songs in the midst of Indonesia's multiethnic society, is to maintain cultural identity. The multi-ethnic Indonesian society has the phenomena of bilingualism and multilingalism which have the potential to cause language change (Brenzinger, 2007). Language change, of course, can threaten the existence of local languages, because generally the number of native speakers in a number of ethnicities is very small. If the survival of the local language-speaking community is fragile, this will potentially change by following the language of the majority (dominant) speaker. When speakers of local 
languages leave their language, it will result in language extinction. Even worse, language extinction has resulted in cultural extinction (Fernando et al., 2010; Wamalwa $\&$ Oluoch, 2013). The presence of cultural radios that broadcast in local languages can directly be an antidote to language extinction (Almurashi, 2017; Dudley, 2019; Hoffmann, 2009).

One of the main steps to protect culture is to preserve the local language. As part of the formation of culture, language is the result of people's interactions with their environment (Sapir, 1970). Therefore, a theory to study the culture of a society emerges, so that we can learn from the language (Salzmann, 2004). Cultural radio broadcasting in local languages shows the true identity of an area and makes the radio has a distinctive appeal (Durant \& Lambrou, 2009).

In Indonesia, besides being widely used and deemed as a part of the civil rights movement, it also has educational and entertainment purposes and plays an important role in preserving Indonesian culture and arts such as wayang, campursari and karawitan. Some radios are even still consistent in preserving them by holding some routine competitions. For example, a public radio in Jogjakarta, RRI Jogjakarta still manages to hold karawitan competition until now (Kriswanto, 2009). However, due to some factors, radio listeners have been decreasing noted from 2003 to 2012 with 10.57\% decline (Innayah and Susanti, 2016). For the spread of its listeners, it is denoted that there are more consumers outside the island of Java compared to those from Java (37\%: 18\%). However, the good news is, when compared to other types of mass media, the role of radio is gaining recognition as a more effective medium for the purpose of preserving local language and culture (Khan et al., 2017; Mu-azu \& Shivram, 2017; Odine, 2013; Zahedi et al., 2013). One advantage of radio that other mass media do not have is the use of spoken language for broadcasting (Hicks, 2013; Lalima, 2013).

The spoken language used by the announcer contains pronunciations and language variations, making it easier for listeners to follow and learn. We do not get pronunciations and language variations in written language (Zhang, 2013). Speech language is the main tool in conveying broadcast content to radio listeners. Speech language can strengthen radio character so it can foster the radio's emotional closeness with its listeners. The message conveyed by the broadcaster will be easier for the listeners to understand with intonation and language variations (Interview with AY, JU, and AS, at Radio Sritanjung FM studio, 22 February 2020).

Spoken language through the speech of the announcer is the best reference for radio listeners to use to communicate to understand the local language. (Akanbi \& Aladesanmi, 2014; Herbert, 1988; Vagle, 1991). The more often radio listeners listen to a local language, they can get to know the local language better than other languages (Muazu \& Shivram, 2017; Vagle, 1991). In addition to that, as stated by Nation and Newton (2009), learners' fluency in using a language will only be achieved under several conditions one of which is the focus of the learners, the process of receiving and conveying the message. Therefore, by receiving the information from the radio, the listeners can try to understand the language, analyze the message and make their own conclusions. It also applies to cultural radio programs that offer local contents in local 
language to their listeners. Thus, it can be concluded that cultural radio programs may also offer its listeners with language learning through their content.

Radio is indeed one of the most frequently used media that still exists in society (Crider, 2012), although public may have different trusts towards a radio depending on the status of the radio, as revealed by Brewer and Pritchard (2008). Nowadays, it has faced lots of challenges because of the emergence of television and internet. There are still, fortunately, some ways to preserve it, one of which is by implementing localism, a condition where a radio is focused on local contents such as local news and discourses (Hood, 2010). In a further study, Wu (2017) also stated that one of the ways to survive in the community and maintain the radio listenership is that a radio station should provide more local contents in its programs. This can be understood, as a certain community may have a certain contentment in certain radio programs. Thus, the radio station must know its targets of audience in a community. Also, it needs to be considered the amount of local entertainment such as music and songs in a local radio. If a local radio is failed to fulfill the expected amount of local content as stated by Saffran (2011) the localism status of a radio station can be a concern.

The cultural programs in the radio have also been long preserved by the government. For example, during the New Order era in Indonesia, radios and TV stations collaborated to work on cultural show programs to spread the traditional culture, in this case is wayang, among young generations. One of the examples of this collaboration was when TVRI Jogjakarta, Kedaulatan Rakyat Newspaper, RRI Jogjakarta, and Jogjakarta Pepadi (Persatuan Pedalangan Indonesia) broadcast wayang kulit every second Saturday of the month (Bogaerts, 2017). Other than that, cultural radio programs may also bring a mission that is to transmit cultural values towards its listeners. The core of cultural values itself relies on beliefs, convictions, communicative habits, and attitudes which are strongly entailed with languaculture (Bert, 2015) that can be found in radio in some ways and programs. Some of the ways that cultural radios have taken is by relying on radio broadcast programs that completely and purely use certain local languages aimed at listeners with certain local cultural identities (Forde et al., 2002; Payton, 2013). The following are the results of tracing cultural programs which are the leading commodities in each cultural radio.

\section{- Cultural Programs on Radio Media FM Surabaya}

Radio Media FM is an alternative entertainment media for the urban community of Surabaya. Surabaya is the second largest city in Indonesia that welcomes newcomers from many districts in East Java province. It then creates some urban communities. These urban communities tend to have strong local ties and tastes to their culture of origin. They are also fond of listening to their traditional music and songs, which they can find in Radio Media FM Surabaya. Radio Media FM Surabaya is a private radio station in Surabaya that broadcasts music and entertainment. One unique thing from this radio station is this radio only broadcasts Indonesian songs both modern and traditional. The traditional songs are Javanese songs in the form of gending, tayub, and campursari. The existence of these traditional Indonesian music has been proven to still stay strong, as these music still have their own loyal listeners and audience until now. Radio Media FM 
itself offers a cultural program called Campursari Media at night. The campursari program is a program which from its inception until now, has a consistent format.

Campursari Media is divided into two segments, the campursari one segment is broadcasted from 18.00 to 21.00 WIB offering contemporary campursari music, which is a combination of modern musical elements with songs with local language lyrics, generally Javanese and a little Using-language. Meanwhile, the campursari two segment which is broadcasted from 22.00 to 01.00 WIB offers classical campursari music (Javanese gending and langgam). This broadcast format has been going on for years and the Radio Media FM also consistently accommodates the bond between listeners, both through interactive telephone channels, song requests, messages and greetings.

Another uniqueness that is difficult to find in other cultural radios, the broadcasters in the campursari segment one and two have the ability to sing and compose campursari songs. The campursari broadcast program can treat the longing for Surabaya migrants who are Javanese and present Javanese music and songs as kelangenan (In Javanese, it means something that is a pleasure, a hobby, a favorite). The reliability of the Radio Media FM culture program is indicated by the choice of broadcast time. The Campursari Media program is regulated and allocated to dominate the prime time (19.00-21.00 WIB), so that the campursari is broadcasted at 18.00-01.00 WIB. The choice of time is not without a reason.

Based on the results of the 2019 media research, the audience for the Campursari Media program is around 400,000 people. This number is the largest number of listeners who listen to cultural broadcasts on Surabaya radio. This number always increases from year to year and the listeners are not all parents, but also young listeners that increase from year to year as well (Interview with WD, at Radio Media FM Studio, 2 March 2020). Campursari is one of Indonesian traditional music that still exists until now. There are also some artists who specialize in campursari songs. They only sing and write campursari songs and introduce them to a broader scope of audience. They make campursari more famous as they arrange campursari in a new way and even mix it with modern music (Achmad, Ida and Mustain, 2020). One of the most famous campursari singers is Didi Kempot who is also known as the legend of campursari. His fans are not only Javanese speakers, but also non-Javanese ones. This proves how influential he is. 


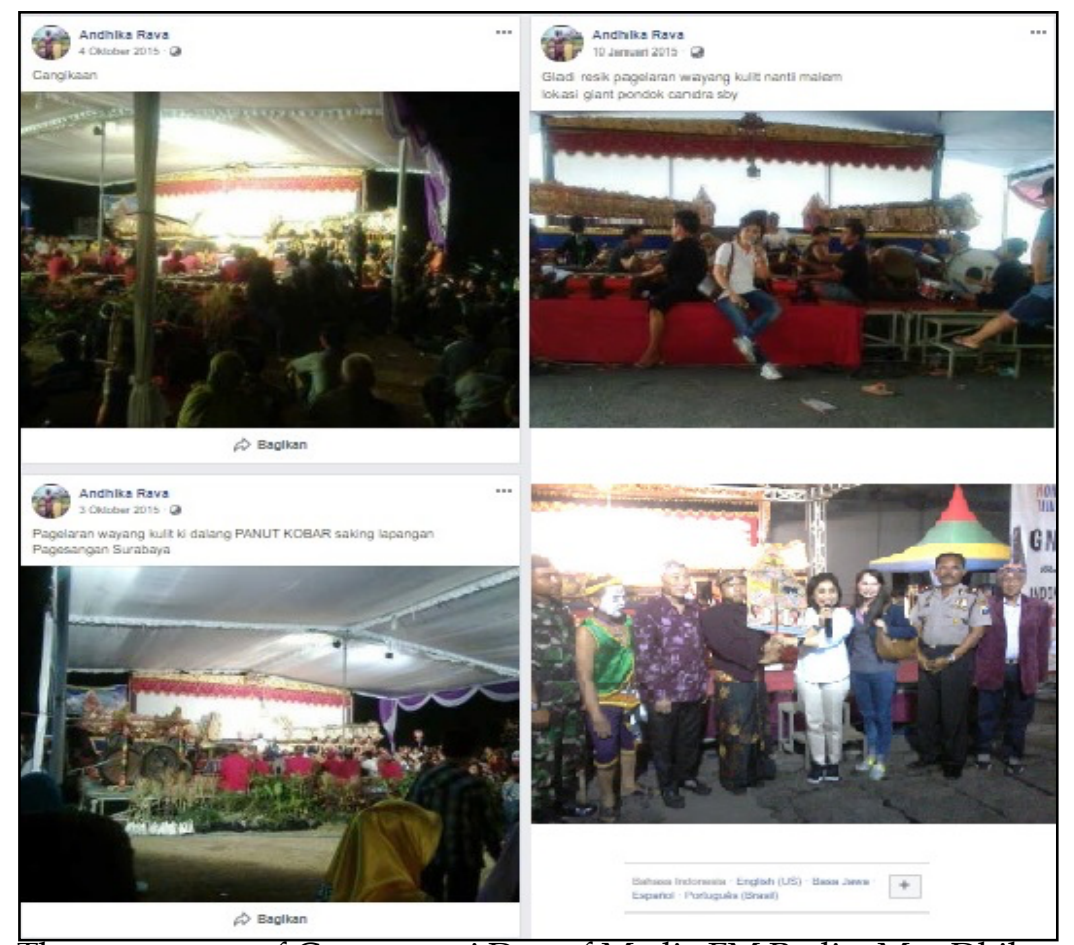

Figure 1: The announcer of Campursari Dua of Media FM Radio, Mas Dhika as known as Ki Panut Kobar, had an activity as a Dalang (source: Facebook account).

The two campursari segments have different age segments as well. In the Campursari One segment, the age range of listeners is 18-74 years. The listeners' musical tastes in the segment are in contemporary music variants, such as: koplo, kendang kempul, hip-hop, reggae, rock, pop, jaranan dangdut and acoustic dangdut. Meanwhile, the Campursari Two segment, which has the listeners' age range of 40-82 years, presents campursari music with musical melodies or repertoires. Musical melodies or repertoires are preferred by this age group, because it gives a peace of mind. The Campursari Two segment is for those who like classical Javanese music which are "older" than Campursari One.

Songs played on Radio Media FM Radio have specific criteria: No lyrics containing SARA elements, gender bias, sexual harassment, polygamy, porn, physical insults, reproach, and cursing. Media FM Radio is a barometer of the success of Campursari songs. Several campursari songwriters in East Java sent samples of songs to get curation from their music directors (Interview with AT, at Radio Media FM studio, 3 February 2020). Radio Media FM is the most worthy of being called a cultural radio in Surabaya, apart from its strength in the dominance of campursari broadcasts and the strength of listeners' loyalty, also because it has a mission to raise local content and encourage local culture potentials, as well as traditional values in the local, national, and international scope.

The success of Radio Media FM's listeners positioning and segmentation strategy as a radio that combines Indonesian pop programs with cultural programs has made its position unshakable as a cultural radio in Surabaya. The carefulness in targeting listeners aged 35 years and over with a background in urban society, can unify listener 
preferences to loyally listen to nostalgic and campursari songs. Although there are other radios that iconically call themselves cultural radio (Java), the strength of Radio Media FM in building its identity as a cultural radio has created a commodification of Javanese art and culture.

\section{- Cultural Programs on Radio Nada FM Sumenep}

Radio Nada FM does have a vision and mission to provide information, music, and entertainment to the people of Sumenep, but it is committed to prioritizing education and emphasizing the distinctive features of Madurese culture and traditions. The entire Madurese culture and traditions that are the content of on-air and off-air programs on Radio Nada FM are always based on the values of the Islamic religion.

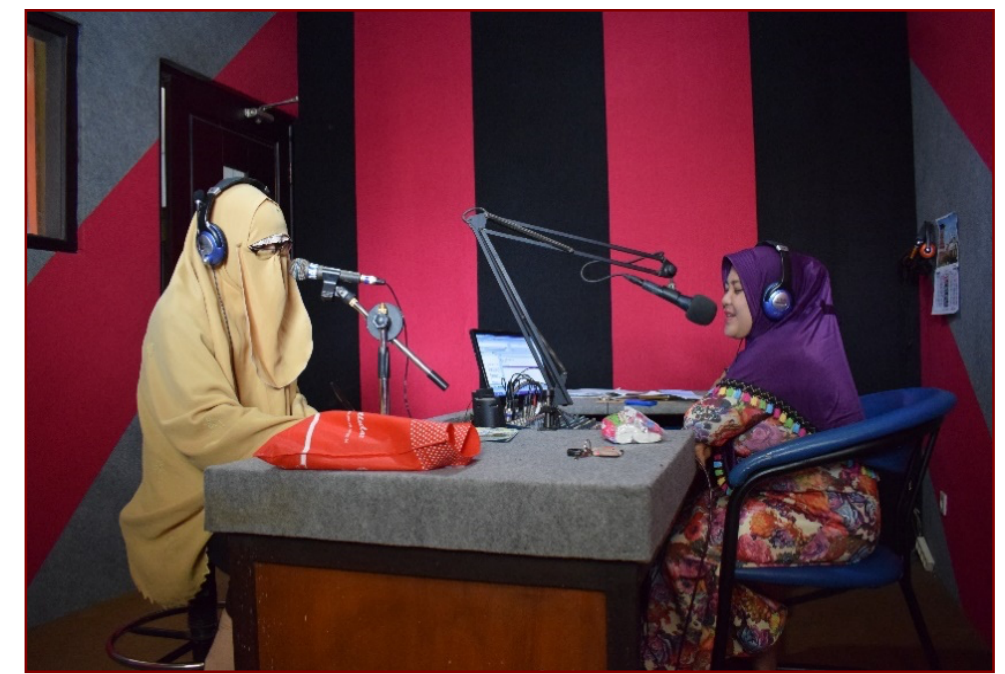

Figure 2: The atmosphere of the broadcast of the Religious Dialogue (Dogma) program with Mbak Merry Rafika. Photographer: Zainal Abidin Achmad

The advantage of Radio Nada FM is consistency in using Madurese language as the main language of broadcast instruction. More than $90 \%$ of music, entertainment and talk show programs use the Madurese language. Especially for the news program, it still uses a ratio of $60 \%$ Madurese and $40 \%$ Indonesian, because it broadcasts various events and information from the Madura region, Indonesia, and various other parts of the world. The broadcast of Islamic education and knowledge programs (study of the Qur'an, hadith, and the yellow book) uses 100\% Madurese language, the Sumenep dialect, which is known to have and apply politeness or fine levels of a language. Radio Nada FM's flagship program is a religious program entitled Nada Sayyidul Ayyam and Dogma (Religious Dialogue) and the cultural programs most liked by listeners and highly demanded by advertisers are Kembang Pangestho, Rojak Cengor, Tambhana Kaso, Andhap Ashor, and Sastra Udara (Interview with IH and IN, at Radio Nada FM studio, 15 April 2020).

As the first private radio broadcast in Madura, it has many advantages. Until now, it has a loyal listeners base covering a wide area of almost the entire island of Madura. The pilot programs that make Radio Nada FM widely known are various off-air programs, such as: new products launch, entertainment stage, recitation, and other promotional 
programs. The off-air program was carried out by involving fans (loyal listeners) to build friendship and foster a sense of belonging to Radio Nada FM.

\section{- Cultural programs on radio Sritanjung FM Banyuwangi}

At the beginning of its establishment, Radio Sritanjung FM was intended as a medium of preaching because at that time there was not a single Islamic boarding school or organization in Banyuwangi that had a radio for da'wah. At the beginning of the registration, it was registered as a National Private Broadcast Radio (RSSN) called Radio Sritanjung with its initial slogan that carried the spirit of locality: Radioe Lare Using. Radio Sritanjung first broadcasted on the frequency $1458 \mathrm{KHz}$ (AM), on September 20, 1992, with a broadcast range of $150 \mathrm{~km}$. The music format was Using-Ethnic 40\%, Dangdut $40 \%$ and Pop 20\%. This radio broadcast moved to the official $93.2 \mathrm{FM}$ frequency on February 15, 2001 with the slogan: "Educating and Entertaining." In 2007 the slogan changed to: "Pride of Banyuwangi" along with the change in frequency to 102.3 FM, according to the frequency rearrangement of the Directorate General of Post and Telecommunication (Interview with AY, at Radio Sritanjung FM Studio, 14 March 2020).

Banyuwangi Regency is an area that has the highest level of radio competition, because it has $10 \mathrm{FM}$ radio stations located and broadcasted in one district. The number of channels available for FM radio broadcasts in Banyuwangi Regency is the largest number in the province of East Java and even in Indonesia. The large number of competitors has made Sritanjung FM Radio continue to innovate to maintain broadcast quality and maintain listeners loyalty.

As a radio which was born under Using-culture and broadcasts 22 hours a day and night, Radio Sritanjung FM designs programs adapted from the existing culture in the Banyuwangi community (Using-Ethnic). The flagship programs which fully broadcasted in Using language are Geredoan and Jenggirat Budoyo Using. The Geredoan Sritanjung program is broadcasted every 13.00-15.00 WIB, Monday to Friday and on Sundays it is broadcasted at 14.00-16.00 WIB. Geredoan means joking or teasing between two or more people. The Geredoan program is broadcasted interactively by opening a telephone line directly from the listeners to the broadcaster, very informal, with light and fresh jokes. The uniqueness of this program is that interactive listeners are obliged to convey wangsalan or rhymes. Through this geredoan, we can recognize the character of the Using Banyuwangi community.

Another program is Jenggirat Budoyo Using, which relies on broadcasting the latest Banyuwangi repertoire. The original Banyuwangi traditional music is Kendang Kempul. However, in its development, Kendang Kempul adopted many other musical elements, from patrol, janger, koplo, dangdut, reggae, jaranan to hip-hop (rap). In this program, the latest information about Banyuwangi and the national the public is discussing one. All information delivered lightly and simply in Using language. The next program is Sritanjung Jenggirat Tangi. This broadcast provides local information from reporters' coverage of Banyuwangi, interspersed with national and international information obtained from the internet. The language of instruction of broadcasters and reporters is Indonesian and Using Language. While the music played is Indonesian Pop. 


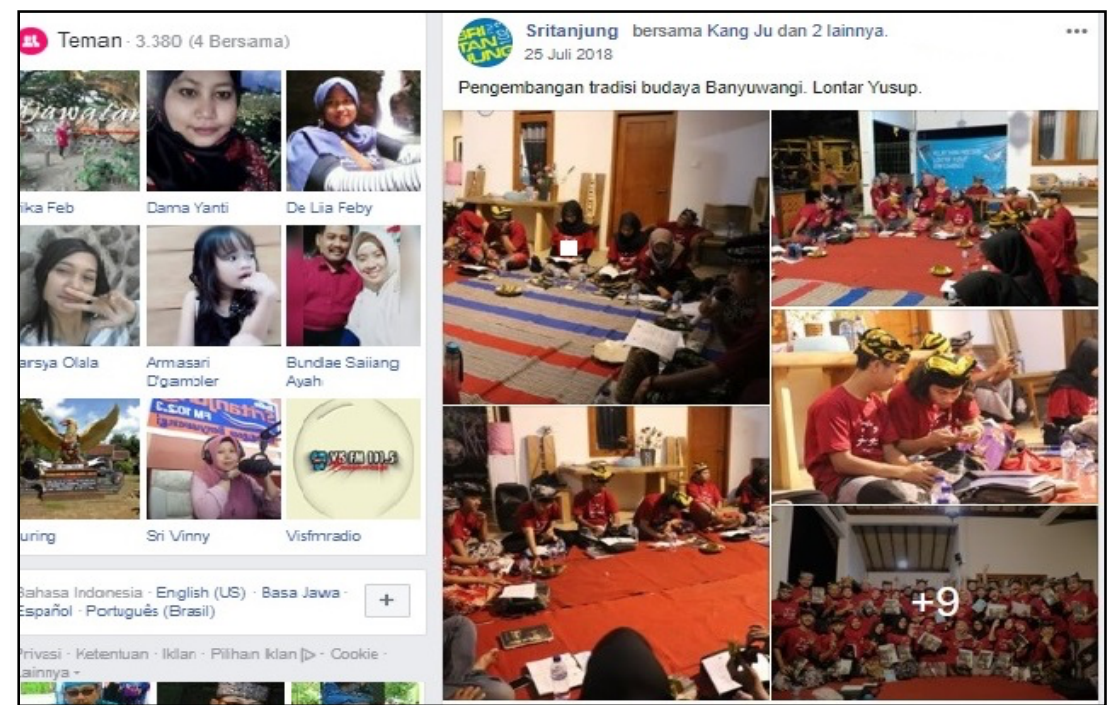

Figure 3: Consistently reporting Banyuwangi cultural programs, one of which is reading lontar. (Source: Facebook account of radio Sritanjung FM).

Radio Sritanjung FM has a concern to involve cultural experts in initiating programs. These cultural experts not only act as resource persons for certain cultural broadcasts, but also contribute in providing suggestions for the naming, designing content, and evaluating cultural programs (Interview with JU, 15 March 2020). The collaboration between cultural observers, producers, programmers, and broadcasters by using Facebook as a means of developing music consumption and music production, is a combination of the motives of the network community in social media: (1) for the purpose of access to content; (2) to have the same interests; (3) for participation purposes; (4) to increase interaction; and (5) to strengthen social identity (Salo et al., 2013).

This proves that Facebook and other social media are an important component of life in today's networked society. Facebook and social media have provided a backdrop for people around the world to communicate, exchange cultures, share knowledge and interact with each other regardless of the distance that separates them. Facebook and other social media promote understanding through interaction to increase mutual understanding between cultures (Sawyer \& Chen, 2012). The collaborative work mentioned above can meet the demands of the cultural environment. Responses from viewers and followers of Kang Ju's Facebook account and Radio Sritanjung FM, show that radio listeners tend to use social media to maintain their love for Using culture as their home culture.

\section{- Cultural Programs on Radio Jodhipati FM Nganjuk}

The purpose of establishing PT. Radio Jodhipati Budaya Nagari is to save, explore, preserve and develop national culture, especially Javanese culture through broadcast media. Radio Jodhipati FM has several objectives in broadcasting, among others: (1) Delivering messages of Javanese culture through information media, including the delivery of regional and national news and so on in Javanese. (2) Maintain and strengthen knowledge of Javanese culture to the community. (3) Preserving and 
disseminating Javanese culture through broadcasting in the fields of art, culture, education, religion and agriculture.

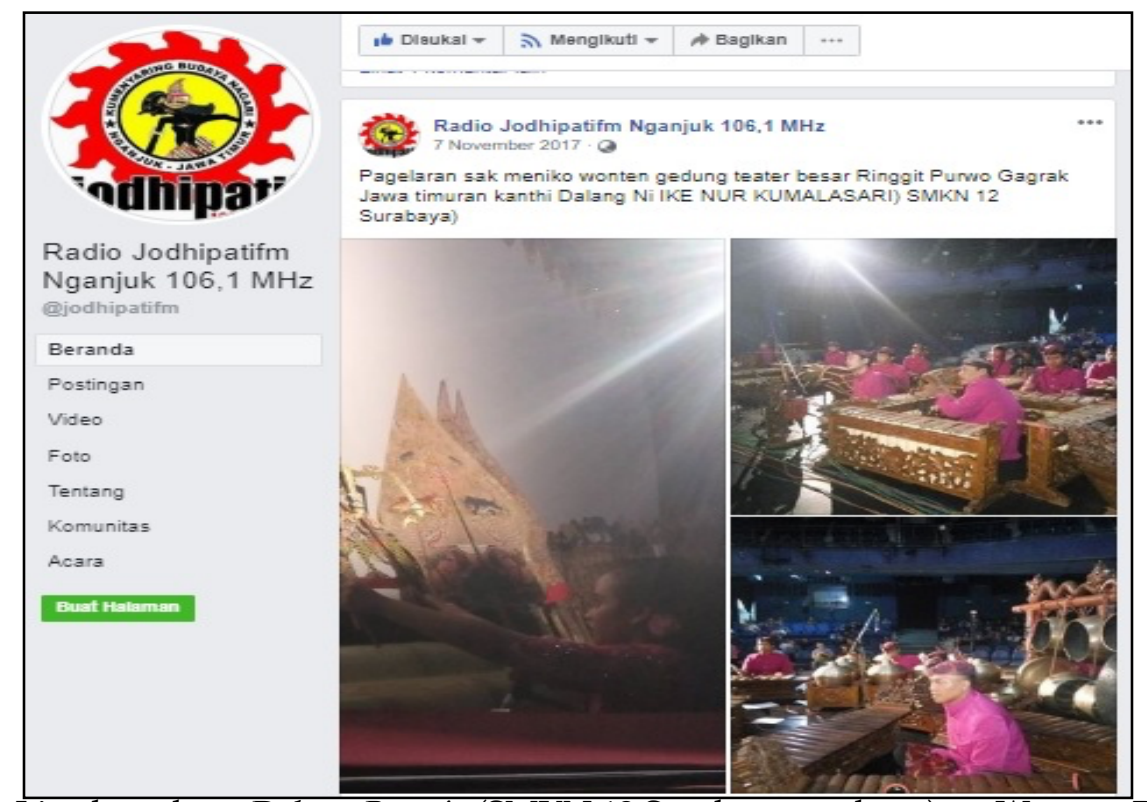

Figure 4: Live broadcast Dalang Remaja (SMKN 12 Surabaya students) on Wayang Day 2017 on Facebook live (Source: Jodhipati FM Facebook account).

Radio Jodhipati FM since its inception has clearly positioned itself as a culture, by reinforcing the vision: "Jodhipati Kumenyaring Nagari, Culture Serves as a Source of Information by Upholding Javanese Culture." In order to realize this vision, Jodhipati FM radio has formulated the following missions: (1) Increasing public understanding that regional culture is the root of national culture; (2) Improve communication and information through radio broadcasts so that people can also feel that they have a regional culture, with the hope of saving, exploring, preserving, and developing the National culture; (3) Inform the progress of developments and empower the community; (4) Encourage the improvement of human resources in the fields of culture, religion, education and agriculture.

One of the flagship and most-awaited programs is wayang kulit (shadow puppet) broadcast. Since wayang has been declared by UNESCO as one of the Masterpieces of the Oral and Intangible Heritage of Humanity, the Indonesian government has been working hard to introduce wayang and make it popular again mainly to younger generations. Wayang has also been used by Indonesians to spread Islam besides as an entertainment (Arifin, 2018) and as part of local resource-based creativity development (Widiyastuti, Rohidi, Florentinus, 2018). Due to its functions, wayang program has long been deemed important to be broadcast in media, including radio. Wayang listeners have been ranging from low to upper-class society. Thus, radio is chosen as one media that spreads wayang as it can reach the society no matter their social classes are. As time goes by, wayang is one of the most widely broadcast cultural radio programs in Java. Many local radios in Java have added wayang as part of their daily programs. This program has always had its loyal audience, most of them are adult listeners who are still keen on listening this program. The radios have always had a schedule when to air wayang show, usually once or twice a week. Nganjuk residence, where Radio Jodhipati 
FM is located, also still preserves wayang as a part of Javanese culture. The success of the initial positioning by broadcasting wayang kulit was strengthened by making various other programs which had strong roots in Javanese culture. Since then, Radio Jodhipati FM has the courage to claim to be a cultural radio.

The Sunaring Ati program is an Islamic da'wah program from well-known religious teachers in Nganjuk Regency and other cities in Indonesia with expectations of realizing inner peace and establishing friendship between listeners and broadcasters. Da'wah broadcasts are accompanied by songs with Islamic nuances. The SAMPUR program (Sangu Makarya Purih Rahayu), is a special broadcast of tayub songs which is Nganjuk's signature art, as an entertainment for farmers who have just returned from activities in the fields. The SARIRAJA program (Campur Sari Radio Jodhipati), a program about campursari songs to accompany people to start their morning activities, is generally aimed at entrepreneur listeners and farmers. The program is about sending greetings by telephone, short messages and WhatsApp groups. The SRIKATON program (Campursari Klasik Maton) plays campursari songs as a stress relief at night with intermittent greetings via telephone, SMS, WhatsApp and Facebook. It makes this program as a means for strengthening friendship and kinship among Jodhipati FM listeners.

The WAYANG KULIT program is the most favorite program. It is in the form of live broadcasts of shadow puppet shows or footage of wayang kulit with various plays and puppeteers with the aim of preserving wayang kulit culture which has been recognized as UNESCO intangible cultural heritage. The MACAPAT program is presented once a week for 3 hours which is aimed to develop the standard Javanese song (Macapat) so that it remains loved by the public. The event segmentation is for teens and adults. Compared to the other 4 radios that also broadcast in Nganjuk District, not a single radio is brave enough to broadcast $100 \%$ in Javanese. Some of the broadcast programs made by Radio Jodhipati FM (the result of planning and participatory involvement of radio listeners and radio management) and the impact of the broadcasted cultural programs (thus creating virtual communities) prove that the network society has actually created what Jan Van Dijk calls digital divide (Van Dijk, 2012).

Those, who have the power to build new social networks in the virtual world, have created new communication groups and even new types of communities. The transition from the social community of off-line radio listeners to online took several forms, including: Sanak Kadang Jodhipati (WhatsApp group), Sritanjung FM Fans (WhatsApp group), Nada FM Lovers (WhatsApp group) and Kadang Campursari Media FM (Facebook Group). Everything has similarities, namely combining interpersonal communication and mass communication. It creates new and better opportunities for communication between senders (private) and receivers (public). In this virtual network, everyone has the same opportunity to talk, exchange text, audio and video. Meanwhile, everyone on the network has the same access to read, watch, listen to and provide feedback. This can only happen in chat groups and virtual instant messaging groups (Herring, 2004). 


\section{Conclusion}

Radio has a more effective role than other mass media in preserving local language and culture. The advantage of radio for language and cultural preservation is on the use of spoken language for broadcasting. The presence of cultural radios that broadcast in local languages and broadcast local cultural content directly can be an antidote to language and cultural extinction. The existence of cultural radios should receive support from the government, because of their role in maintaining local cultural values, maintaining the values of national identity, maintaining social solidarity and harmony, and fostering a sense of love for the country.

\section{Acknowledgments}

We would like to give out appreciate to radio management of Radio Sritanjung FM Banyuwangi, Radio Jodhipati FM Nganjuk, Radio Nada FM Sumenep, and Radio Media FM Surabaya. We also thank you for PD PRSSNI Jawa Timur, Lemhannas RI, Dean of Faculty of Social and Political Sciences \& Dean on Faculty of Law UPN Veteran Jawa Timur, cultural radio listeners' communities in East Java, and the reviewers of the ETNOSIA: Jurnal Etnografi Indonesia.

\section{Conflicts of interest}

Author declares no conflict of interest.

\section{References}

Achmad., Z. A. (2019). Integrasi Program Dakwah dan Budaya: Studi Etnografi Virtual Mediamorfosis Radio Nada FM Sumenep Madura. Jurnal Komunikasi Islam, 09(2), 238-263. https://doi.org/10.15642/jki.2019.9.2.239-263

Achmad, Z. A. (2020a). Pergeseran Relasi Antara Pendengar Radio dengan Institusi Radio dalam Masyarakat Jaringan (Studi Etnografi Virtual pada Radio-radio Budaya di Jawa Timur yang Bermediamorfosis). Universitas Arilangga.

Achmad, Z. A. (2020b). Review Buku: Mediamorphosis. In Menghadapi Tantangan New Normal di Indonesia. Penerbit Administrasi Negara.

Achmad, Z. A., \& Alamiyah, S. S. (2015). Relation Between Political Economic of Media with the Strategies for Radio Positioning to Maintain the Existence of Commercial Radio (Case Study of JJFM Radio in Surabaya). International Conference on Democacy and Accountability (ICoDA), 1, 188-193.

Achmad, Z. A., \& Ida, R. (2018). Etnografi Virtual Sebagai Teknik Pengumpulan Data dan Metode Penelitian. The Journal of Society \& Media, 2(2), 130-145. https:// doi.org/10.26740/jsm.v2n2.p130-145

Achmad, Z. A., \& Ida, R. (2019). The shifting role of the listeners in the mediamorphosis process of culture radio: A case study of Jodhipati 106.1 FM. Masyarakat, Kebudayaan Dan Politik, 32(3), 240. https://doi.org/10.20473/mkp.v32i32019.240-250

Achmad, Z. A., Ida, R., \& Mustain, M. (2020). A Virtual Ethnography Study: The Role of Cultural Radios in Campursari Music Proliferation in East Java. Etnosia: Jurnal Etnografi Indonesia, $5(2), 221-237$.

Akanbi, T. A., \& Aladesanmi, O. A. (2014). The Use of Indigenous Language in Radio Broadcasting: A Platform for Language Engineering. Open Journal of Modern Linguistics, 04(04), 563-572. https:// doi.org/10.4236/ojml.2014.44049

Akpan, C. S. (2004). The Impact of The New Communication Technologies on The Broadcast Industry. International Journal of Communication, 1, 70-78.

Al-hassan, S., Andani, A., \& Abdul-malik, A. (2011). The Role of Community Radio in Livelihood Improvement: The Case of Simli Radio. Field Actions Science Reports, 5(October 2012), 0-6. 
Albarran, A., Mierzejewska, B., \& Jung, J. (Eds.). (2006). Handbook of Media Management and Economics. Routledge. https://doi.org/10.4324/9781410615589

Almurashi, W. A. (2017). WHY WE SHOULD CARE ABOUT LANGUAGE DEATH. International Journal of English Language and Linguistics Research, 5(5), 62-73.

Angelone, L. (2018). Virtual Ethnography: The Post Possibilities of Not Being There. Mid-Western Educational Researcher, 31(3), 275-295.

Ardiansyah, F. A. (2017). Strategi dakwah bil lisan Nyai Hj. Naimah di Sumenep. Universitas Islam Negeri Sunan Ampel Surabaya.

Arifin, F. (2018). Promoting Wayang Kulit as a Media in Internalizing Islamic Values. Edukasia Islamika, 152. doi: 10.28918/jei.v3i2.1685

Arps, B. (2009). Osing Kids and the banners of Blambangan, Ethnolinguistic identity and the regional past as ambient themes in an East Javanese town. Wacana, 11(1), 1-38.

Baltzis, A. (2004). The Mediamorphosis of the Artistic Communication. Seminar of the European Research Network Digital Radio Cultures in Europe (COST A20), 18. http://www.drace.org/\%5Cnhttp://users.auth.gr/ baltzis/en/abstracts_en/seminar_04 _mediamorphosis_en.html\%5Cnhttp://users.auth.gr/ baltzis/papers/seminar_04_medi amorphosis.pdf

Barber, S. (2010). Smooth jazz: A case study in the relationships between commercial radio formats, audience research and music production. Radio Journal: International Studies in Broadcast $\mathcal{E}$ Audio Media, 8(1), 57-70. https:/ /doi.org/10.1386/rajo.8.1.51_1

Benjamin, W. (2005). Walter Benjamin, Selected Writings Volume 2, Part 2 1931-1934 (M. W. Jennings, H. Eiland, \& G. Smith (Eds.)). Belknap Press of Harvard University Press.

Benkler, Y. (2006). The Wealth of Networks. In German Law Journal (Vol. 7). https:/ / doi.org/10.1177/0894439307301373

Bogaerts, E. (2017). Mediating the local: Representing Javanese cultures on local television in Indonesia. Journal of Southeast Asian Studies, 48(2), 196-218. doi: $10.1017 / \mathrm{s} 0022463417000042$

Bonini, T. (2014). The New Role of Radio and Its Public in the Age of Social Network Sites. First Monday, 19(6). https:/ / doi.org/http:/ / dx.doi.org/10.5210/fm.v19i6.4311

Brenzinger, M. (2007). Language Diversity Endangered (M. Brenzinger (Ed.)). Mouton de Gruyter.

Brewer, P., \& Pritchard, D. (2008). Ideology and Public Trust in Radio as a Source for Local News. Journal of Radio E Audio Media, 15(2), 124-135. doi: 10.1080/19376520802397219

Cochrane, P., Jeffery, G., Dower, R. C., Garnham, J., \& McGregor, S. (2008). The Arts and Community Radio: A CapeUK research report.

Crider, D. (2012). A Public Sphere in Decline: The State of Localism in Talk Radio. Journal of Broadcasting E Electronic Media, 56(2), 225-244. doi: 10.1080/08838151.2012.678514

Denzin, N. K., \& Lincoln, Y. S. (2000). Handbook of Qualitative Research (N. K. Denzin \& Y.S. Lincoln (Eds.); 2nd ed.). Sage Publications Ltd.

Deuze, M., Bruns, A., \& Neuberger, C. (2007). Preparing For An Age Of Participatory News. Journalism Practice, 1(3), 322-338. https:/ / doi.org/10.1080/17512780701504864

Dia, S. (2002). Radio Broadcasting and New Information and Communication Technologies: Uses, Challenges and Prospects.

Dudley, D. (2019). Why we should care about rural aging. Generations, 43(2), 94-98.

Durant, A., \& Lambrou, M. (2009). Language and Media: A Resource Book for Students. Routledge.

Faisal, A. M., \& Alhassan, A. (2018). Community Access and Participation in Community Radio Broadcast: Case of Radio Gaakii, Ghana. Journal of Development and Communication Studies, 5(2), 85. https://doi.org/10.4314/jdcs.v5i2.6

Fernando, C., Valiäjrvi, R. L., \& Goldstein, R. A. (2010). A model of the mechanisms of language extinction and revitalization strategies to save endangered languages. Human Biology, 82(1), 47-75. https:/ / doi.org/10.3378/027.082.0104

Fidler, R. (1997). Mediamorphosis: Understanding New Media. Pine Forge Press.

Forde, S., Foxwell, K., \& Meadows, M. (2002). Creating a Community Public Sphere: Community Radio as a Cultural Resource. Media International Australia Incorporating Culture and Policy, 103(1), 56-67. https:/ / doi.org/10.1177/1329878X0210300109

Gilloch, G. (2002). Walter Benjamin: Critical constellations. In Choice (Vol. 40, Issue 3). Polity Press. https://doi.org/loc?

Hair, N., \& Clark, M. (2003). An Enhanced Virtual Ethnography: The Role Of Critical Theory. 
$\begin{array}{llll}\text { Exploring } \quad \text { Meaning of'critique'in } & \text { 4he, }\end{array}$ http://merlin.mngt.waikato.ac.nz/ejrot/cmsconference/2003/proceedings/exploringthe meaning/Hair.pdf

Herbert, J. C. (1988). Broadcast Speech and the Effect of Voice Quality on the Listener (Issue October). https://core.ac.uk/download/pdf/77023622.pdf

Herring, S. (2004). Slouching toward the ordinary: current trends in CMC. New Media \& Society, 6, 26-36.

Hicks, D. (2013). Radio Broadcasting in Regional or Minority Languages.

Hine, C. (2000). Virtual Ethnography. Sage Publications Ltd.

Hine, C. (2004). Virtual Ethnography Revisited. In Online Reearch Methods, Research Methods Festival.

Hine, C. (2017). Virtual Ethnography: Modes, Varieties, Affordances. In N. Fielding, R. M. Lee, \& G. Blank (Eds.), The SAGE Handbook of Online Research Methods (pp. 401-415). SAGE. https://doi.org/10.4135/9780857020055.n14

Hoffmann, M. (2009). Endangered Languages, Linguistics, and Culture: Researching and Reviving the Unami Language of the Lenape. Linguistics, May.

Hood, L. (2010). Radio Recentered: Local News Returns Home. Journal of Radio \& Audio Media, 17(2), 151-166. doi: 10.1080/19376529.2010.519652

Innayah, N., \& Susanti, M. (2016). The Role of The Listener and Government Institutions in Educational Radio Broadcasts (Peran Serta Pendengar dan Lembaga Pemerintah dalam Siaran Radio Pendidikan). Journal Pekommas, 1(1), 21. doi: 10.30818/jpkm.2016.2010103

Inkinen, E., \& Tuominen, A. (2013). Brand Image of Radio Nostalgia in Finland. Haaha-Helia University of Applied Sciences.

Kessler, L. (2012). Choosing an Effective Positioning Slogan. Innis Maggiore Ad Agency. https://www.innismaggiore.com/blog/choosing-effective-positioning-slogan/

Khan, M. A. A., Khan, M. M. R., Hassan, M., Ahmed, F., \& Haque, S. M. R. (2017). Role of Community Radio for Community Development in Bangladesh. The International Technology Management Review, 6(3), 94. https://doi.org/10.2991/itmr.2017.6.3.3

King, G. (2015). Hearing community radio listeners: A storytelling approach for community media audience research. Participations, Journal of Audience and Reception Studies, 12(2), 121136. http:/ / www.participations.org/Volume 12/Issue 2/7.pdf

Kriswanto. (2009). Peranan Radio Republik Indonesia Yogyakarta dalam Pelestarian Karawitan. Resital: Jurnal Seni Pertunjukan, 10(1). doi: 10.24821/resital.v10i1.470

Kusuma, A., Purbantina, A. P., Nahdiyah, V., \& Khasanah, U. U. (2020). A Virtual Ethnography Study: Fandom and social impact in digital era. Etnosia: Jurnal Etnografi Indonesia, 5(2), 238251. https://doi.org/10.31947/etnosia.v5i2.10898

Lalima. (2013). Language Learning Through Media: Role of Radio. Techno LEARN: An International Journal of Edcational Technology, 3(1), 67-74.

Lloyd, D. (2015). How To Make Great Radio: Techniques and tips for today's broadcasters and producers. Biteback Publishing.

May, A. (2013). Why Radio is Still Relevant in a Digital Age. Just Media. http://justmedia.com/2013/08/why-radio-is-still-relevant-in-a-digital-age/

Mu-azu, I. A., \& Shivram, G. P. (2017). The Impact of Radio Broadcast in Local Dialect on Rural Community. Journal of Applied and Advanced Research, 2(3), 114. https://doi.org/10.21839/jaar.2017.v2i3.76

Mytton, G. (1992). Handbook on Radio and Television Audience Research. International Broadcasting Audience Research BBC World Service.

Newton, J., \& Nation, I. (2009). Teaching ESL/EFL listening and speaking. Routledge: New York.

Nguyen, T. T. T. (2008). The Role of Radio and TV in the Life of Ethnic Minorities in Vietnam (Case Study: The H'Mong People in Lao Cai and Lai Chau Province). University of Tromso.

O'Neill, B. (2007). Digital Technologies and the Future of Radio: Lessons from the Canadian Experience. University of Lincoln, Lincoln, UK.

Odine, M. (2013). Use of Radio to Promote Culture in South Africa. Journal of Radio \& Audio Media, 20(1), 181-196. https:// doi.org/10.1080/19376529.2013.777341

Payton, M. (2013). Action Stations, The Output and Impact of Commercial Radio. Radio Centre.

Peeters, Bert. (2015). Language and Cultural Values: Adventures in Applied Ethnolinguistics. International Journal of Language and Culture 2(2). 133-141. doi: 10.1075/ijolc.2.2.001pe 
Perala, R., Helle, M., \& Johnson, S. (2012). Developing and testing new audience research methods. ECREA Conference, 1-33.

Price, M., Haas, S., \& Margolin, D. (2008). New Technologies and International Broadcasting: Reflections on Adaptations and Transformations. The ANNALS of the American Academy of Political and Social Science, 616(1), 150-172. https:// doi.org/10.1177/\%0A0002716207312033

PRSSNI Jawa Timur. (2018). Profil Anggota PRSSNI Jawa Timur. http:/ / www.radiojatim.com/index.php?option=com_content\&view=article\&id=1\&Itemi $\mathrm{d}=154 \#$

Rothenbuhler, E. W. (1996). Commercial Radio as Communication. Journal of Communication, 46(1), 125-143. https:// doi.org/10.1111/j.1460-2466.1996.tb01464.x

Saffran, M. (2011). Effects of Local-Market Radio Ownership Concentration on Radio Localism, the Public Interest, and Listener Opinions and Use of Local Radio. Journal of Radio \& Audio Media, 18(2), 281-294. doi: 10.1080/19376529.2011.616469

Salo, J., Lankinen, M., \& Mäntymäki, M. (2013). The Use of Social Media for Artist Marketing: Music Industry Perspectives and Consumer Motivations. International Journal on Media Management, 15(1), 23-41. https:// doi.org/10.1080/14241277.2012.755682

Salzmann, Z. (2004). Language, Culture, and Society: an Introduction to Linguistic Anthropology (3rd ed.). Westview Press.

Sapir, E. (1970). Language. In D. G. Mandelbaum (Ed.), Culture, Language and Personality (p. 207). University of California Press.

Sawyer, R., \& Chen, G.-M. (2012). The Impact of Social Media on Intercultural Adaptation. Intercultural Communication Studies, XXI(2).

Schneider, V. (2012). Governance and Complexity. In David Levi-Faur (Ed.), Oxford Handbook of Governance, (pp. 129-142). Oxford University Press.

Schoneboom, A. (2007). Diary of a working boy: Creative resistance among anonymous workbloggers. Ethnography, 8(4), 403-423. https://doi.org/10.1177/1466138107083559

Setianingrum, V. M. (2012). Transformasi Media Radio, Studi Kasus di Radio Giga FM (She Radio) Surabaya dan Radio Pandowo (Pas FM) Tulungagung Jawa Timur [Universitas Gadjah Mada]. https:// doi.org/2434-H-2012

Stewart, P. (2010). Essential Radio Skills: How to present a radio show (2nd ed.). A\&C Black.

Storsul, T., \& Fagerjord, A. (2010). Digitization and Media Convergence. In The International Encyclopedia of Communication. John Wiley \& Sons, Ltd. https://doi.org/10.1002/9781405186407.wbiecd039

Storsul, T., \& Stuedahl, D. (Eds.). (2007). Ambivalence Towards Convergence, Digitalization and Media Change. Nordicom - Göteborg University.

Sweeting, A. (2007). The Costs of Product Repositioning: The Case of Format Switching. Manuscript.

Tomasello, T. K., Lee, Y., \& Baer, A. P. (2010). "New media" research publication trends and outlets in communication, 1990-2006. New Media and Society, 12(4), 531-548. https:// doi.org/10.1177/1461444809342762

Vagle, W. (1991). Radio language - spoken or written? International Journal of Applied Linguistics, 1(1), 118-131. https://doi.org/10.1111/j.1473-4192.1991.tb00009.x

Van Dijk, J. A. G. M. (2012). The Network Society: Social Aspects of New Media (3rd ed.). SAGE Publications Ltd.

Walker, J. (2004). Rebels on the Air: An Alternative History of Radio in America (2nd ed.). New York University Press.

Wamalwa, E. W., \& Oluoch, S. B. J. (2013). Language Endangerment and Language Maintenance: Can Endangered Indigenous Languages of Kenya Be Electronically Preserved? International Journal of Humanities and Social Science, 3(7), 258-265.

Warren, S. (2005). Radio, The Book (4th ed.). Elsevier Focal Press.

Widiyastuti, E., Rohidi, T.R., and Florentinus, T.S. (2018). Background of the Creation of Heri Dono's Wayang Legenda as a Basis of Developing Local Resource-Based Creativity. The Journal of Education Development, 6(2), 165-175.

Wilkinson, C. (2015). Young People, Community Radio and Urban Life. Geography Compass, 9(3), 127-139. https:// doi.org/10.1111/gec3.12197

Wirth, M. O. (2006). Issues in Media Convergence. In A. Albarran, B. Mierzejewska, \& J. Jung (Eds.), Handbook of Media Management and Economics (1st ed., pp. 18-35). Routledge. 
Wu, L. (2017). Evaluating Local News on the Radio. Electronic News, 11(4), 229-244. doi: $10.1177 / 1931243117694672$

Zahedi, A., Ghoolizadeh, A., \& Sadeghi, S. (2013). Defining Role of the Radio of Town in Promotion of a Culture of Citizenship. Kuwait Chapter of Arabian Journal of Business and Management Review, 2(10), 89-95?

Zhang, B. (2013). An Analysis of Spoken Language and Written Language and How They Affect English Language Learning and Teaching. Journal of Language Teaching and Research, 4(4), 834-838. https://doi.org/10.4304/jltr.4.4.834-838 